Section Editor

John J. Millichap, MD

Teaching NeuroImages:

\title{
Typical neuroimaging features in high-altitude cerebral edema
}

Victor Hugo Rocha Marussi, MD

José Luiz Pedroso, MD, $\mathrm{PhD}$

Alexandre Maksoud

Piccolo, MD

Orlando G. Barsottini, $\mathrm{MD}, \mathrm{PhD}$

Fabiano Moulin de Moraes, MD, MSc

Acary Souza Bulle

Oliveira, MD, PhD

Leonardo Furtado Freitas, MD

Lázaro Luís Faria do Amaral, MD

Correspondence to

Dr. Pedroso:

jlpedroso.neuro@gmail.com

Download teaching slides: Neurology.org

\section{Figure Brain MRI}
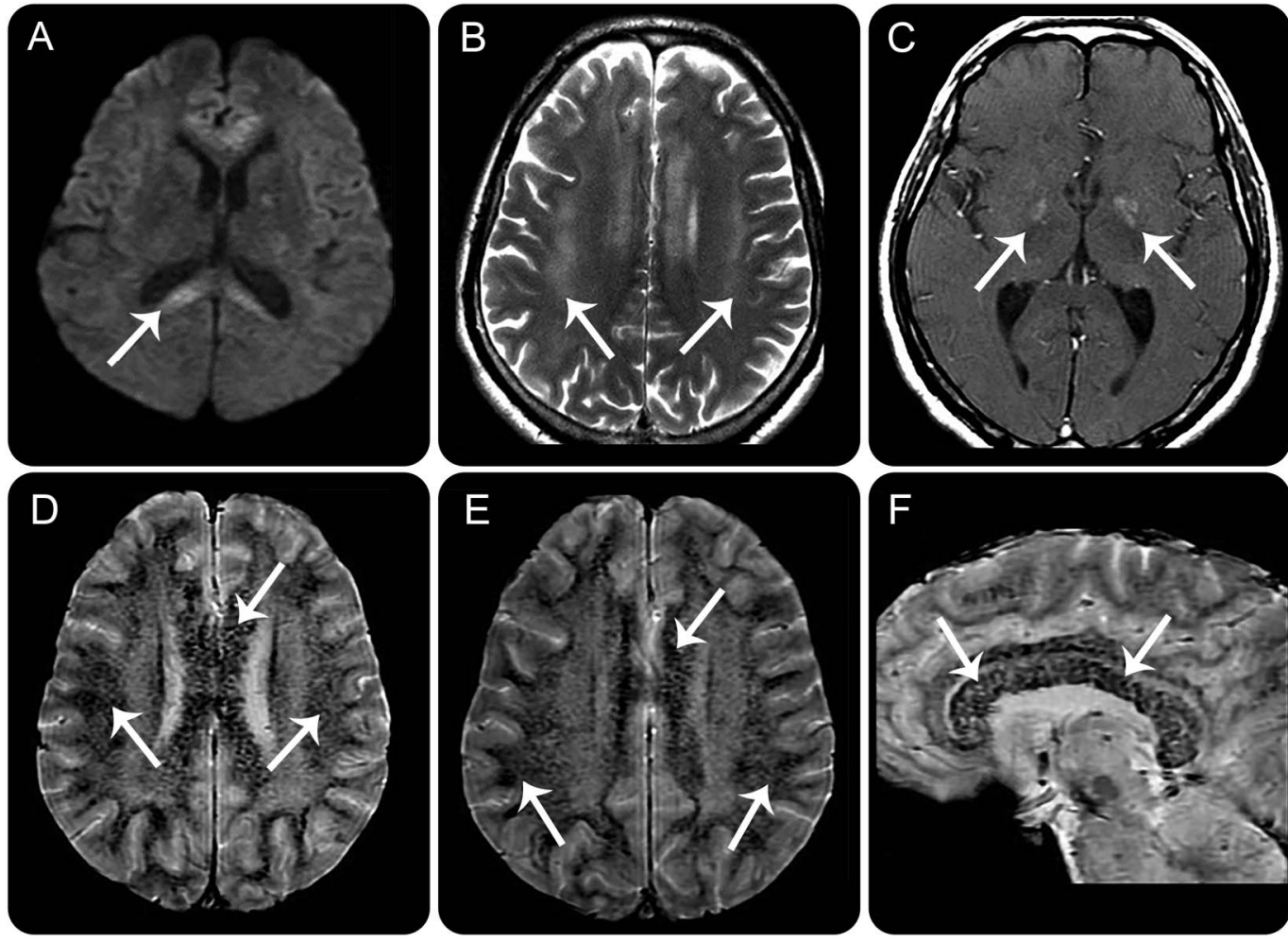

(A) Diffusion-weighted MRI shows hyperintense signal in the corpus callosum. (B) T2-weighted MRI discloses white matter changes caused by vasogenic edema. (C) T1-weighted MRI shows enhancement by contrast in globus pallidus. (D-F) Susceptibility-weighted imaging shows diffuse microhemorrhages. These are brain MRI abnormalities observed in highaltitude cerebral edema.
A 61-year-old man presented with thunderclap headache followed by loss of consciousness, 2 days after arriving in Atacama Desert, Andes Mountains, Chile, at 4,000 meters. Examination showed coma. Mechanical ventilation was necessary. He had progressive improvement after transfer to low altitudes. Brain MRI showed diffuse vasogenic edema and microhemorrhages (figure), and high-altitude cerebral edema (HACE) was diagnosed.

HACE is a high morbidity condition characterized by vasogenic edema, causing acute consciousness impairment, due to physiologic effects of traveling to high altitude. ${ }^{1}$ Typical neuroimaging features encompass white matter changes, corpus callosum involvement, and diffuse microhemorrhages. ${ }^{2}$ Treatment includes supplemental oxygen, descent, and medication such as dexamethasone.

\section{AUTHOR CONTRIBUTIONS}

Dr. Marussi: case report project conception, organization, and execution; imaging conception, organization, and execution; writing of the first draft, review and critique. Dr. Pedroso: case report project conception, organization, and execution; imaging conception, organization, and execution; writing of the first draft, review and critique. Dr. Picollo: case report project conception, organization, and execution; imaging conception, organization, and execution; writing of the first draft, review and critique. Dr. Barsottini: imaging conception, organization, and execution; writing of the first draft, review
From Hospital Beneficência Portuguesa de São Paulo (V.H.R.M., A.M.P., L.F.F., L.L.F.d.A.), Medimagem; and Department of Neurology and Neurosurgery (J.L.P., O.G.B., F.M.d.M., A.S.B.O.), Universidade Federal de São Paulo, Brazil.

Go to Neurology.org for full disclosures. Funding information and disclosures deemed relevant by the authors, if any, are provided at the end of the article. 
and critique. Dr. Moraes: imaging conception, organization, and execution; writing of the first draft, review and critique. Dr. Oliveira: imaging conception, organization, and execution; writing of the first draft, review and critique. Dr. Freitas: imaging conception, organization, and execution; writing of the first draft, review and critique. Dr. Amaral: imaging conception, organization, and execution; writing of the first draft, review and critique.

\section{STUDY FUNDING}

No targeted funding reported.
DISCLOSURE

The authors report no disclosures relevant to the manuscript. Go to Neurology.org for full disclosures.

\section{REFERENCES}

1. Wilson $\mathrm{MH}, \mathrm{Newman} \mathrm{S}$, Imray $\mathrm{CH}$. The cerebral effects of ascent to high altitudes. Lancet Neurol 2009;8:175-191.

2. Schommer K, Kallenberg K, Lutz K, Bärtsch P, Knauth M. Hemosiderin deposition in the brain as footprint of highaltitude cerebral edema. Neurology 2013;81:1776-1779. 


\section{Neurology}

Teaching NeuroImages: Typical neuroimaging features in high-altitude cerebral edema Victor Hugo Rocha Marussi, José Luiz Pedroso, Alexandre Maksoud Piccolo, et al. Neurology 2017;89; e176-e177

DOI 10.1212/WNL.0000000000004544

This information is current as of October 2, 2017

\begin{tabular}{|c|c|}
\hline $\begin{array}{l}\text { Updated Information \& } \\
\text { Services }\end{array}$ & $\begin{array}{l}\text { including high resolution figures, can be found at: } \\
\text { http://n.neurology.org/content/89/14/e176.full }\end{array}$ \\
\hline Supplementary Material & $\begin{array}{l}\text { Supplementary material can be found at: } \\
\text { http://n.neurology.org/content/suppl/2017/10/02/WNL.0000000000004 } \\
544 . D C 1\end{array}$ \\
\hline References & $\begin{array}{l}\text { This article cites } 2 \text { articles, } 1 \text { of which you can access for free at: } \\
\text { http://n.neurology.org/content/89/14/e176.full\#ref-list-1 }\end{array}$ \\
\hline Subspecialty Collections & $\begin{array}{l}\text { This article, along with others on similar topics, appears in the } \\
\text { following collection(s): } \\
\text { All Clinical Neurology } \\
\text { http://n.neurology.org/cgi/collection/all_clinical_neurology } \\
\text { MRI } \\
\text { http://n.neurology.org/cgi/collection/mri } \\
\text { Other cerebrovascular disease/Stroke } \\
\text { http://n.neurology.org/cgi/collection/other_cerebrovascular_disease_s } \\
\text { troke }\end{array}$ \\
\hline Permissions \& Licensing & $\begin{array}{l}\text { Information about reproducing this article in parts (figures,tables) or in } \\
\text { its entirety can be found online at: } \\
\text { http://www.neurology.org/about/about_the_journal\#permissions }\end{array}$ \\
\hline Reprints & $\begin{array}{l}\text { Information about ordering reprints can be found online: } \\
\text { http://n.neurology.org/subscribers/advertise }\end{array}$ \\
\hline
\end{tabular}

Neurology ${ }^{\circledR}$ is the official journal of the American Academy of Neurology. Published continuously since 1951, it is now a weekly with 48 issues per year. Copyright (C 2017 American Academy of Neurology. All rights reserved. Print ISSN: 0028-3878. Online ISSN: 1526-632X.

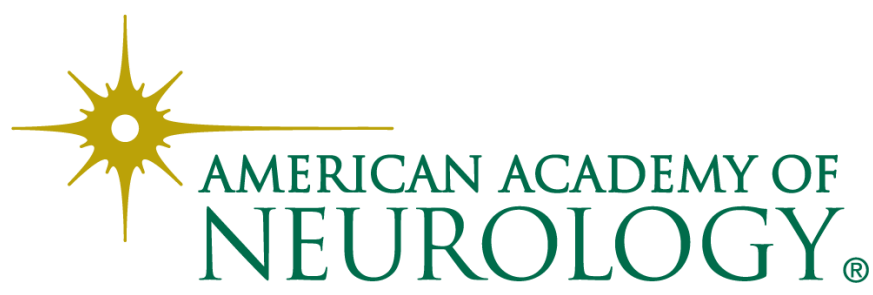

